\title{
EXAMINATION METHODS FOR WATERPROOFING INJECTION SCREENS IN VARIOUS BUILDING MATERIALS
}

\author{
PREISKOVALNE METODE ZA VBRIZGANE HIDROIZOLACIJSKE \\ MEMBRANE V RAZLIČNIH GRADBENIH MATERIALIH
}

\author{
Rostislav Drochytka, Vít Černý, Jindřich Melichar \\ Brno University of Technology, Faculty of Civil Engineering, Veveří 331/95, 60200 Brno, Czech Republic \\ drochytka.r@fce.vutbr.cz,cerny.v@fce.vutbr.cz,melichar.j@fce.vutbr.cz \\ Prejem rokopisa - received: 2015-07-01; sprejem za objavo - accepted for publication: 2016-06-09
}

doi:10.17222/mit.2015.192

\begin{abstract}
Practically all building structures are to some extent struck by wetness. Usually, there is no need to take measures, but when there finally are, the redevelopment method of wet masonry by additional creating a waterproofing injection screen in building structures is nowadays one of the most widespread methods for treating rising capillary wetness. The main advantages of this method are the relatively quick and easy application and the excellent final efficiency. Factors like wetness, temperature or type of building material have a large influence on the injection screens' functionality. The main focus of this paper is testing the specially created various types of injection gels' penetration abilities and their final efficiency in dependence on these factors.

Keywords: redevelopment of wet masonry, injection screens
\end{abstract}

Praktično vse zgrajene zgradbe prizadene vlaga. Običajno ni potrebe po ukrepih, kadar pa so potrebni, je dandanes najbolj razširjen postopek sanacije vlažnih zidov dodatno vbrizgavanje hidroizolacije v zidove za preprečevanje dviganja kapilarne vlage. Glavne prednosti te metode so relativno hitra in lahka izvedba ter odlična končna učnkovitost. Faktorji, kot: vlaga, temperature in vrsta gradbenega materiala, imajo velik vpliv na učinkovitost vbrizgane prepreke. Glavni poudarek tega članka je preizkušanje sposobnosti penetracije posebnih kreiranih gelov ter njihova končna učinkovitost, v odvisnosti od teh faktorjev.

Ključne besede: obnova vlažnih zidov, vbrizgane prepreke

\section{INTRODUCTION}

Every construction is affected by a number of negative factors, which are, for example, impacts of snow, wind or freezing, but the most significant influence on buildings usually comes from wetness. The disturbance of even one building material used in construction results in advancing the decrease of the durability in masonry. If this state of affairs occurs, then it is necessary to take a step to redevelopment of the building. ${ }^{1}$

Wetness in masonry used to be manually decreased only by mechanical methods in the past. These methods were based on additional cutting or breaking through masonry and applying various types of hydro-isolation. Obviously, the disadvantage of these procedures is that they have a big influence on buildings statics.,3

One of the most widespread methods for treating rising wetness is the method of creating additional hydrophobic injection screen, which stops this event from happening. Substances used in order to create injection screen are called injection gels.

Many building constructions, especially those which are considerably old and fragile, would not withstand any other mechanical procedures which have usually a big impact on structure statics. Usually, it is just these types of buildings that are struck by rising wetness in lower levels and cellars. In that case the usage of injection gels is the ideal solution. ${ }^{4}$
The biggest advantages of using the injection screen method is the low mechanical impact of the treated building, because only a horizontal line of drill holes need to be applied in order to use this method. That allows the treatment of old or damaged structures, which would not withstand any other more invasive methods of treatment. The other advantage is the relatively quick application. ${ }^{5,6}$

\section{EXPERIMENTAL PART}

In cooperation with Betosan Co. six injection gels were developed. The main focus of the research was to create a series of laboratory testing methods, by which it would be possible to determine the properties of each gel, compare them with each other and afterwards choose one recapture with ideal properties for further testing. Each of the gels is silicate based and contains a share of secondary materials, which are in comparison with foreign materials much cheaper. Each of the tested materials contains a portion of silica fume, zeolite, bentonite, clay minerals and metakaolin.

Each recapture of injection gels had to be tested using laboratory methods. In that order reduced samples were created. Size of each sample was roughly the size of a half brick. It was $(55 \times 120 \times 120) \mathrm{mm}$. In dependence on the requirements of each method, the tested 

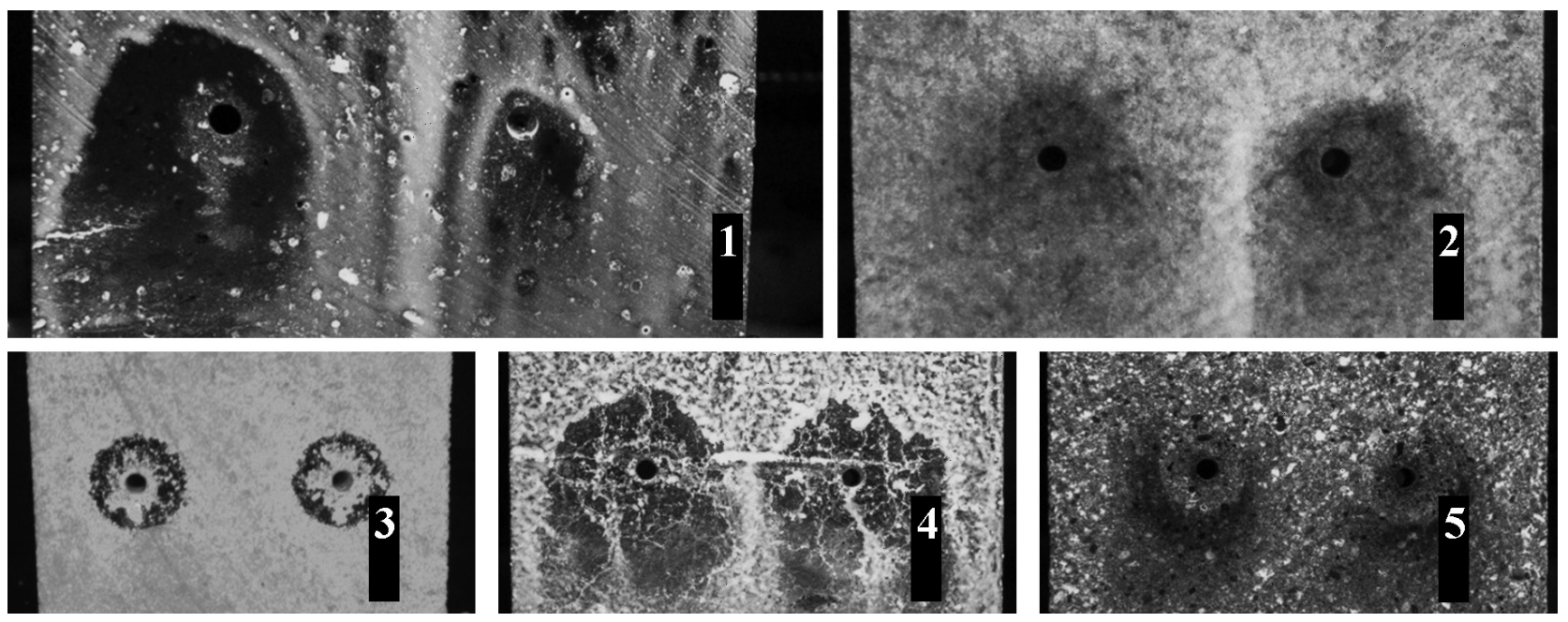

Figure 1: Samples with applied humidity indicator at temperature of $25^{\circ} \mathrm{C}$ ( 1 - burnt brick, 2 - sandstone, 3 - aerated concrete, 4 - mason mortar 1, 5 - mason mortar 2)

Slika 1: Vzorci z nanosom indikatorja vlage pri temperaturi $25^{\circ} \mathrm{C}$ (1 - žgana opeka, 2 - peščenjak, 3 - beton z zračnimi delci, 4 - malta 1 , 5 - malta 2

materials were either applied on the surface or injected into the reduced drill holes.

Types of tested materials were chosen in order to cover the range of the most commonly used materials in building structures. It was burnt brick, sandstone, aerated concrete and two types of mason mortar.

In order to validate the properties of each injection material, a series of four testing methods was created. The first of these methods is measuring the surface permeability. In this case injection gels were applied on the tested surface of the test samples and the results are measured as the volume of water soaked up into the sample in given time through a certain surface.

The second laboratory method is a determination of the absorption power which is established by completely immersing the test samples in the water for a determined time and calculated as the difference between the weight of dry sample and sample entirely soaked with water. In this case the whole surface of the test sample was covered by a waterproofing gel. The results of the testing are pictured in two diagrams below. The results were split into two pictures, because of the significantly lower results of water absorption in both kinds of masonary mortar.

The next testing method was measuring the capillary attraction, which is carried out by treating the surface of the test samples, and placing their bottom part onto the plastic grate. In lower parts of samples two drill holes were created in which gels were injected. This testing method was executed by using only three gels, which showed the best results in the previous testing. It was gel $\mathrm{B}, \mathrm{C}$ and $\mathrm{D}$. The results are established as the ratio of the soaked up water in given time through a given surface of dried up sample.

The fourth testing method was observing the penetration rate of each injection gel in dependence on the temperature of the building materials. The tested tempe- ratures were $5{ }^{\circ} \mathrm{C}, 10{ }^{\circ} \mathrm{C}, 25^{\circ} \mathrm{C}$ and $30{ }^{\circ} \mathrm{C}$. In this case two drill holes were created in the middle line of each sample in which each injection gel was applied. After maximum penetration of the sample it was cut in has perpendicularly to the line of the drill holes. Example specimens of each building material are shown in Figure 1.

The last research method was testing of injection gels in-situ. Based on the results of the laboratory testing mentioned before, the one gel with the most suitable properties was chosen. In order to test the gel in-situ, the brick wall which is a part of real building structure was chosen. First step was a determination of the wetness of building material $100 \mathrm{~mm}$ above the place, where drill holes were about to be created. The wetness was determined using a resistance moisture meter. The next step was creating a line of 10 drill holes with a diameter of $12 \mathrm{~mm}$ and a distance $110 \mathrm{~mm}$ with a depth of 310

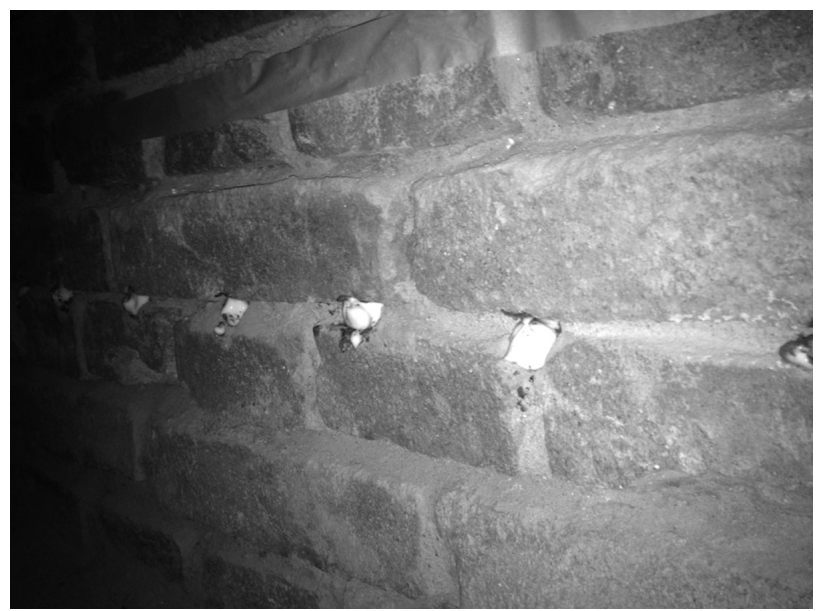

Figure 2: Drill holes filled by waterproofing gel

Slika 2: Izvrtane luknje, napolnjene z hidroizolacijskim gelom 
R. DROCHYTKA et al.: EXAMINATION METHODS FOR WATERPROOFING INJECTION SCREENS IN ...

$\mathrm{mm}$. This line of drill holes was created above the terrain level in the outside. The total thickness of the tested wall was $360 \mathrm{~mm}$. After that the drill holes were cleaned by compressed air. In next step the drill holes were filled using waterproofing gel and left to penetrate for $30 \mathrm{~d}$. Drill holes with injected gel can be seen in Figure 2.

\section{RESULTS AND DISCUSSION}

From the results of the water permeability measuring it is apparent that the presence of the injection gels significantly decreases the water volume absorbed through the treated surface compared to the reference samples. The most valuable decrease was observed for the samples treated by gels D and E, as observed in Figure 3 .

From the results of the absorption power determination of first three building materials is apparent that the presence of all six types of gels decreases the volume of absorbed water through the surface. The most significant decrease was observed in samples treated by samples of injection gels B, C and D, as shown in Figure 4.

Practically the same trend was observed in both types of masonary mortar as in three previously tested building materials, which can be observed in Figure 5.

The testing results of the three gels applied into five building materials are pictured in the Figure 6.

It is again obvious that the presence of injection gels decreases the volume of absorbed water by capillary

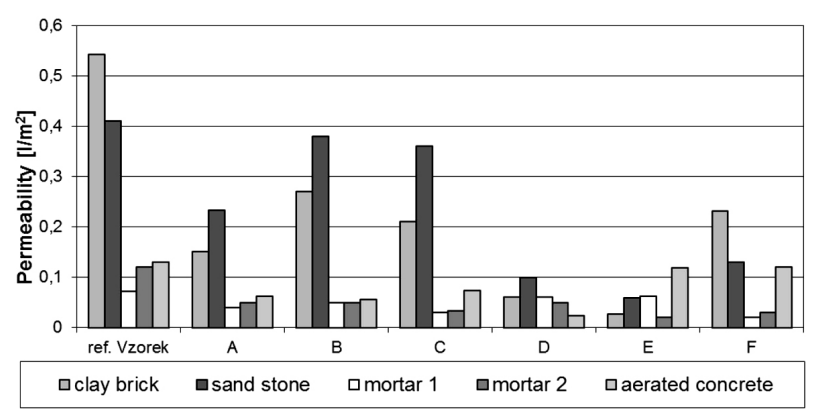

Figure 3: Results of measuring surface permeability of various building materials treated by six different waterproofing gels

Slika 3: Rezultati merjenja prepustnosti površine različnih gradbenih materialov, obdelanih s šestimi hidroizolacijskimi geli

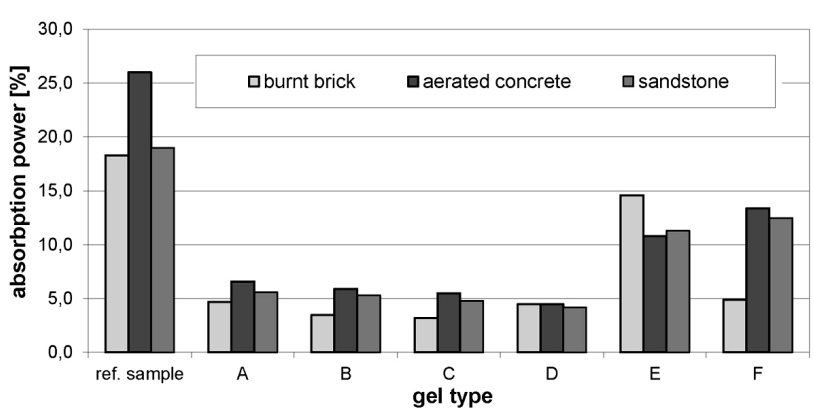

Figure 4: Results of burnt brick, aerated concrete and sandstone absorption power measurements

Slika 4: Rezultati merjenja moči absorpcije pri žgani opeki, porobetonu in peščenjaku

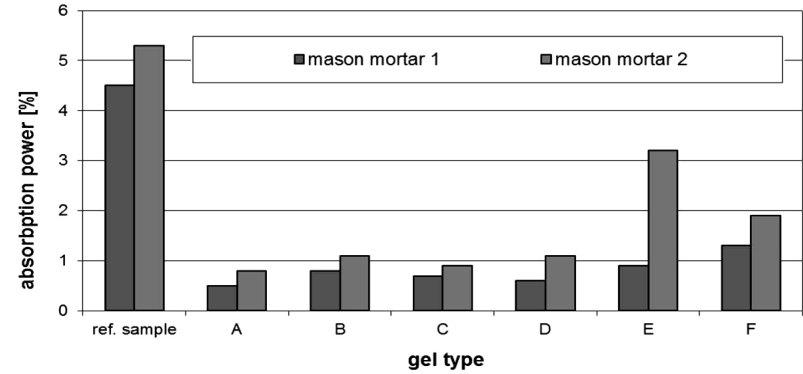

Figure 5: Results of masonary mortar 1 and masonary mortar 2 volume absorption measurements

Slika 5: Rezultati meritev volumske absorpcije zidarske malte 1 in zidarske malte 2

power in each tested material. The best results were observed in the samples treated by gel B.

In order to clearly observe the sector penetrated around each hole the UV humidity indicator was applied and the results were measured in millimeters. The results are displayed in Table $\mathbf{1 .}$

Table 1: Results of penetration rate measurement in dependence on various temperatures

Tabela 1: Rezultati merjenja hitrosti penetracije v odvisnosti od različnih temperatur

\begin{tabular}{|c|c|c|c|c|c|}
\hline & \multicolumn{5}{|c|}{ Penetration rate in dependence on temperature } \\
& \multicolumn{5}{|c|}{$\left({ }^{\circ} \mathrm{C}\right)$} \\
\hline treatment & $5^{\circ} \mathrm{C}$ & $1{ }^{\circ} \mathrm{C}$ & $25^{\circ} \mathrm{C}$ & $35^{\circ} \mathrm{C}$ & average \\
\hline gel B & 30.0 & 36.0 & 34.8 & 44.4 & 36.4 \\
\hline gel C & 28.8 & 33.2 & 41.8 & 45.4 & 37.6 \\
\hline gel D & 26.8 & 35.8 & 36.0 & 36.0 & 33.8 \\
\hline
\end{tabular}

The results show that the largest penetration rate at all temperatures was achieved in the samples treated by injection gel $\mathrm{C}$, closely after that is gel $\mathrm{B}$ and lowest penetration rate was observed in samples penetrated by gel D.

After this period of time the wetness was determined in same spots as before the application. The results are displayed in table below. The relative wetness of the surrounding environment was $45.5 \%$ and the temperature of the air was $17.8{ }^{\circ} \mathrm{C}$. The consumption of injection gel on one drill house was about $320-370 \mathrm{~mL}$, which

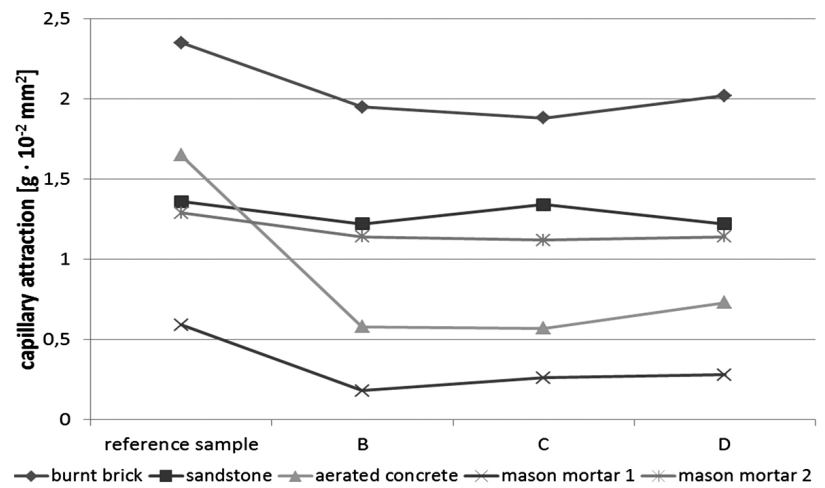

Figure 6: Results of capillary attraction measuring

Slika 6: Rezultati merjenja kapilarnosti 
R. DROCHYTKA et al.: EXAMINATION METHODS FOR WATERPROOFING INJECTION SCREENS IN ...

shows that all the drill holes were uniformly filled by the gel. The results are displayed in Table 2.

Table 2: Results of mass wetness determination before and after $30 \mathrm{~d}$ of application

Tabela 2: Rezultati določanja mase vlage pred in po 30 dneh uporabe

\begin{tabular}{|c|c|c|c|c|}
\hline & \multicolumn{4}{|c|}{ Mass wetness (\%) } \\
\hline & Brick & $\begin{array}{l}\text { Brick - } \\
\text { average }\end{array}$ & $\begin{array}{l}\text { Mason } \\
\text { mortar }\end{array}$ & $\begin{array}{l}\text { Mason } \\
\text { mortar - } \\
\text { average }\end{array}$ \\
\hline \multirow{3}{*}{$\begin{array}{c}\text { Before } \\
\text { application }\end{array}$} & 7.9 & \multirow{3}{*}{5.6} & 6.7 & \multirow{3}{*}{5.1} \\
\hline & 5.0 & & 3.1 & \\
\hline & 4.0 & & 5.6 & \\
\hline \multirow{3}{*}{$\begin{array}{c}30 \text { days } \\
\text { after } \\
\text { application }\end{array}$} & 1.2 & \multirow{3}{*}{0.7} & 1.7 & \multirow{3}{*}{1.2} \\
\hline & 0.7 & & 1.3 & \\
\hline & 0.3 & & 0.7 & \\
\hline
\end{tabular}

From the results of the in-situ testing it is obvious that the presence of injection gels in the building structure distinctively decreases the reading of the mass moisture in the building materials by $80 \%$.

\section{CONCLUSIONS}

From all the results of the executed laboratory methods it is clear that it is possible to determine the properties of injection gels by their usage. By measuring the surface permeability, the absorption volume and the capillary attraction of reference samples and samples treated by six injection gels the results were obtained, by which comparison the specter of the tested gels was narrowed from six to three samples. Testing of the penetration rate under different temperatures of building materials that were injected by three types of gels is also an efficient method for comparing the properties of each gel.

There might also be other methods of examination, like testing the penetration rate of each gel in dependence on various moistures, creating bigger samples like columns and testing them or testing real damaged structures in-situ. But that is the object of further research.

\section{Acknowledgements}

This paper has been created under the project number LO1408 "AdMaS UP - Advanced Materials, Structures and Technologies".

\section{REFERENCES}

${ }^{1}$ R. Drochytka, J. Melichar, P. Dohnálek, Penetration Rate of Various Injection Gels in Dependence on Wetness of Building Materials, Applied Mechanics and materials, 752-753 (2015), 720-723, doi:10.4028/www.scientific.net/AMM.752-753.720

${ }^{2}$ R. Drochytka, J. Melichar, P. Dohnálek, Measuring of the Penetration Rate of Injection Gels during Remediation of Various Building Materials, Advanced Materials research, 103 (2014) 08, 219-222, doi:10.4028/www.scientific.net/AMR.1000.219

${ }^{3}$ J. Melichar, R. Drochytka, V. Cerny, Experimental Testing of Hydroinsulating Injection Screens, Advanced Materials research, 860-863 (2014), 2327-2330, doi:10.4028/www.scientific.net/ AMR.860-863.2327

${ }^{4}$ J. Melichar, R. Drochytka, P. Dohnálek, Laboratory Verifying of Injection Screens Efficiency, Advanced Materials Research, 897 (2014), 325-328, doi:10.4028/www.scientific.net/AMR.897.325

${ }^{5}$ WTA directive 4-4-04/D: Injection of masonry against capillary wetness, Praha, Tauris, 2005

${ }^{6}$ J. Melichar, R. Drochytka, P. Dohnálek, Remediation of Old Sandstone Structures via Hydroinsulating Injection Gels, Advanced Materials Research, 1122 (2015), 51-54, doi:10.4028/www.scientific.net/AMR.1122.51 